\title{
Contribution of biofilm to water quality, survival and growth of juveniles of the freshwater crayfish Cherax quadricarinatus (Decapoda, Parastacidae)
}

\author{
Verónica E. Viau a , Juan M. Ostera a, Analía Tolivia a, Eduardo L.C. Ballester ${ }^{\text {b }}$, \\ Paulo C. Abreu ${ }^{c}$, Enrique M. Rodríguez ${ }^{\mathrm{a}, *}$ \\ a Department of Biodiversity and Experimental Biology, FCEyN, University of Buenos Aires, Ciudad Universitaria, Pab. II, C1428EHA Buenos Aires, Argentina \\ b Shrimp Culture Laboratory, Federal University of Paraná, Campus Palotina, Av. Pioneiro 2153, Palotina, PR, CEP 85950-000, Brazil \\ ' Institute of Oceanography, Federal University of Rio Grande, Av. Itália, KM 8, Rio Grande, RS, CEP 96201-900, Brazil
}

\section{A R T I C L E I N F O}

\section{Article history:}

Received 28 June 2011

Received in revised form 6 October 2011

Accepted 8 October 2011

Available online 20 October 2011

\section{Keywords:}

Biofilm

Cherax quadricarinatus

Natural production

Artificial substrates

Growth

Water quality

\begin{abstract}
A B S T R A C T
The effect of biofilm as an alternative food source and/or a complement for improving culture was assayed for early and advanced juveniles of Cherax quadricarinatus. For both kinds of juveniles, higher values of survival were seen in the experimental groups provided with either biofilm (B) or a combination of both formulated food and biofilm $(B+F)$, compared to the group only receiving formulated food $(F)$. Such higher survival was associated to a better water quality maintained by biofilm, in terms of low levels of both ammonium and nitrite, together with high levels of $\mathrm{pH}$ and dissolved oxygen. As for growing, specific growth rate was higher in the groups fed with formulated food, but only for early juveniles. Considering the crayfish biomass at the end of the experiment (i.e., an integrative index of both survival and growth), the best results were seen in the $\mathrm{B}+\mathrm{F}$ group, for both kind of juveniles. The main micro-organisms present in biofilm were chlorophytas, xantophytas, pennate diatoms, cyanobacteria, flagellates, ciliates, rotifers and nematodes. Most of these items were found in the stomach of crayfishes fed on biofilm. The hepatopancreatic levels of total lipids were higher in animals of both B $+\mathrm{F}$ and $\mathrm{F}$ groups, compared to those of B group, while energetic reserves in the abdominal muscle showed no differences among experimental groups, for any kind of juveniles. Therefore, biofilm could be considered as a good complement for the culture system of $C$. quadricarinatus juveniles, mainly by improving survival through the maintenance of a good water quality. Combination of biofilm and formulated food has shown the best results, in terms of both survival and growth of juvenile crayfish.
\end{abstract}

(c) 2011 Elsevier B.V. All rights reserved.

\section{Introduction}

Cherax quadricarinatus (von Martens), or redclaw, is a crayfish species native to the tropical region of Queensland, northern Australia, with high commercial potential. Production of this species on farms, either in Australia or other countries, has been significantly increased during the last decades, due to the advantages for its culturing (Medley et al., 1994). According to Jones (1995, 1997), life cycle of $C$. quadricarinatus comprises a relatively long embryonic development ( 6 to 10 weeks), during which successive larval stages take place within the egg, to finally hatch a first juvenile stage. After two successive molts, juveniles become completely independent from their mother. In farms of Argentina, the culture of this species starts with an indoor incubation and growing stage of about 3 to 4 months long. After hatching, recently independent (early) juveniles are commonly maintained in hatcheries for 2 to 4 weeks. Advanced juveniles (near $1 \mathrm{~g}$ of body weight) are later transferred to

\footnotetext{
* Corresponding author. Tel.: +54 114576 3300; fax: + 541145763384 . E-mail address: enrique@bg.fcen.uba.ar (E.M. Rodríguez).
}

larger tanks (nurseries) until they achieve a body weight of near $5 \mathrm{~g}$. After that, juveniles are maintained in earthen ponds for 6 to 9 months, until they reach a market weight of $50 \mathrm{~g}$ or higher.

C. quadricarinatus is a facultative omnivorous species; its diet includes both plant and animal materials, as well as detritus. The gastric mill of $C$. quaricarinatus juveniles has been described as morphologically adapted for the consumption of both detritus and zooplankton (Loya-Javellana et al., 1994). Some studies have shown that in culture conditions, zooplankton leads to a higher crayfish growth than other food sources (Austin et al., 1997; Jones, 1995; Verhoef et al., 1998). Consumption of phytoplankton by crayfish under culture conditions has not been previously reported.

Several formulated diets have been developed to achieve an acceptable survival and growth of $C$. quadricarinatus juveniles, optimizing the percentage of protein, lipids and other nutrients (Campaña-Torres et al., 2006; Cortés-Jacinto et al., 2003; Gutiérrez and Rodríguez, 2010). However, formulated food represents $60 \%$ of the total operational costs of aquaculture farms (Tacon, 1999), which can be even higher in intensive cultures.

The term biofilm is referring to a micro-organisms community, associated to an organic matrix formed on a surface submersed in a 
water body. Such micro-organisms are involved in the transference of organic matter through most trophic chains and in the biochemical cycles verified in aquatic ecosystems (Decho, 1990; Meyer-Reil, 1994). Different cultured crustacean species have improved either growth or survival when biofilm was provided to them as a food source (Abreu et al., 2007; Ballester et al., 2007; Thompson et al., 2002, among others). Besides, the water quality of culture systems was frequently improved by the utilization of biofilm (Bratvold and Browdy, 2001; Holl et al., 2011; Thompson et al., 2002, among others). However, only one preliminary study has been reported on a crayfish species (Cherax destructor) concerning the possible benefit of biofilm (Jones and Thanuthong, 2002).

The current study was aimed at evaluating the effect of biofilm, as an alternative and/or complementary food source, on survival and growth of both early and advanced juveniles of $C$. quadricarinatus. The effect of biofilm on water quality maintenance was also evaluated.

\section{Materials and methods}

\subsection{Experimental design}

C. quadricarinatus ovigerous females were purchased from a local dealer (Pinzas Rojas SRL, Tucumán, Argentina). A short-time after hatching, early juveniles ( $N=288$, mean weight $0.10 \pm 0.05 \mathrm{~g}$ ), corresponding to the first independent juvenile instars, were selected for the experiment. Besides, another group of early juveniles was fed every day with a commercial diet (TetraColor®; $47.5 \%$ crude protein) for one month, in order to obtain advanced juveniles $(\mathrm{N}=234$, mean weight $0.98 \pm 0.43 \mathrm{~g}$ ) for a second experiment.

Each experiment comprised 30 days, beginning by early February (early juveniles) or by early March (advanced juveniles); all the experiments were carried out in Buenos Aires ( $34^{\circ} 36 \mathrm{~W}, 58^{\circ} 23 \mathrm{~S}$ ). A zero water exchange system was used, only adding dechlorinated tap water to compensate water for evaporation losses. Glass aquaria $\left(0.24 \mathrm{~m}^{2}\right.$ bottom surface), filled with $60 \mathrm{~L}$ of continuously aerated water, were employed as experimental units $(\mathrm{N}=9$ to each group of juveniles). A number of either 32 early juveniles or 26 advanced juveniles were assigned to each aquarium, yielding a density of 133 and 111 animals $/ \mathrm{m}^{2}$, respectively. These densities were similar to others previously used for juveniles of the same species (Jones, 1995; Masser and Rouse, 1997). A mean water temperature of $25 \pm 2{ }^{\circ} \mathrm{C}$ and a photoperiod of 14:10 ( $\mathrm{L}: \mathrm{D}$, natural light) were maintained throughout the experimental period.

The following experimental groups, by triplicate, were run for each group of juveniles:

\begin{tabular}{|c|c|}
\hline B & juveniles only fed on biofilm. \\
\hline $\mathrm{B}+\mathrm{F}$ & $\begin{array}{l}\text { juveniles fed with either biofilm and formulated fish meal } \\
\text { (TetraColor®; } 47.5 \% \text { crude protein). }\end{array}$ \\
\hline & juveniles only fed on formulated fish meal (same as above). \\
\hline
\end{tabular}

Formulated meal, successfully used in previous studies on C. quadricarinatus (Chaulet et al., 2008; Viau and Rodríguez, 2010) was given every day at a percentage of 10 (early) or 5 (advanced) of juvenile biomass, in specially feeding trays, designed according to Wasielesky et al. (2006). Briefly, each tray was composed by a cylindrical plastic base (15 cm de diameter), coupled to a vertical PVC pipe $(30 \mathrm{~cm}$ long, 1.5 inch diameter) for loading food. Two trials were placed in each aquarium, in order to ensure that all juvenile could easily access to the food provided.

Biofilm used to feed juveniles was developed during $30 \mathrm{~d}$ before starting the experiment, on plastic nets $(50 \times 27 \mathrm{~cm}, 1 \mathrm{~mm}$ mesh size) vertically placed in aquaria containing a heterotrophic medium, prepared from an initial inoculum taken from natural body water and added as $15 \%$ of the aquaria volume water. To help biofilm development a little portion (50 mg/aquarium/day) of the commercial diet was added, as a source of nitrogenous and phosphorous. The biofilm was considered as mature when chlorophyll $a$ reached a concentration near $5 \mu \mathrm{g} / \mathrm{cm}^{2}$, according to Thompson et al. (2002). At this time, 4 plastic sheets were transferred to each aquarium assigned to both $B$ and $B+F$ groups. Group $F$ received the same number of plastic sheets with no biofilm formed, that were also periodically replaced during the experiment, to avoid biofilm formation. Additionally, aquaria of all groups received some PVC pipes as refuges (32 of $1 \mathrm{in}$. and 26 of $1.5 \mathrm{in}$. diameter, for each aquarium of early and advanced juveniles, respectively), which were daily withdrawn for cleaning them of any biofilm eventually formed.

\subsection{Biofilm monitoring}

Weekly, three small samples $(4 \times 4 \mathrm{~cm})$ were cut from the plastic nets of each aquarium corresponding to both $\mathrm{B}$ and $\mathrm{B}+\mathrm{F}$ groups, at $20 \mathrm{~cm}$ deep, in order to determine the biofilm dry weight and chlorophyll $a$ concentration, as well to characterize the micro-organisms presented. Additionally, samples of sheets were also taken from the F group, in order to check if any biofilm formation took place.

To determine dry weight, the first sample was placed in stove at $60{ }^{\circ} \mathrm{C}$ until constant weight, estimating by difference the biofilm dry biomass at a precision of $\pm 0.1 \mathrm{mg}$. In the second sample, chlorophyll a concentration was determined after removing fresh biofilm from plastic with a soft brush; biological material was then filtered through a micro-fiberglass GF/F (Muntkell@, $47 \mathrm{~mm}$ diameter, $0.7 \mu \mathrm{m}$ pore size). Finally, the filter was placed in a glass vial containing $8 \mathrm{~mL}$ $60 \%$ ethanol in total darkness, for $24 \mathrm{~h}$. Chlorophyll $a$ concentration was determined spectrometrically at 665 and $750 \mathrm{~nm}$, before and after the acidification with $\mathrm{HCl} 0.1 \mathrm{~N}$, according to the equations proposed by Marker et al. (1980).

To characterize micro-organisms, the biofilm of the third sample was gently removed and preserved in a glass vial filled with $20 \mathrm{~mL}$ of distilled water and formaldehyde at $4 \%$ final concentration. Later, three aliquots were separately and systematically analyzed under binocular microscope (Nikon SMZ 645, 100 to $1000 \times$ magnifications), to identify the main items presented. Determination of genera was made according previous studies (Canter-Lund and Lund, 1995; Da Cunha, 1913; Hartley, 1996; Krammer and Lange-Bertalot, 1986, 2004; Lee et al., 2000).

\subsection{Variables measured on juvenile crayfish}

At the end of the experiment, both survival and body wet weight of all juveniles (precision $\pm 0.1 \mathrm{mg}$ ) were determined, after drying the external surface of animals. After that, the following variables were calculated:

- Specific growth rate $(\mathrm{SGR})=\left[\left(\ln W_{f}-\ln W_{i}\right) / T\right] \times 100$, where $W_{f}$ and $W_{i}$ are the final and initial body weights, respectively, and $T$ is the time elapsed from the beginning of the experiment.

- Biomass, expressed as $\mathrm{g} / \mathrm{m}^{2}$ : at the end of the experiment, body weight of all animals belonging to a same experimental group were summed, and then divided by the surface of the three aquaria assigned to each group.

Additionally, 15 juveniles from each group, either early or advanced, were cryo-anaesthetized and the stomach (pro-ventriculus) dissected to determine their content. For this purpose, the stomach content from each dissected juvenile was carefully inspected under binocular microscope (Nikon SMZ 645, 100 to $1000 \times$ magnifications), in order to identify the micro-organisms presented. Eventually, samples were photographed under microscope, to further verify the identity of any item. In addition, at the end of the assay both abdominal muscle and hepatopancreas were dissected from both early 
$(\mathrm{N}=10)$ and advanced $(\mathrm{N}=10)$ juveniles, to determine the levels of glycogen (according to Van Handel, 1965), lipids (according to Folch et al., 1957; Fring and Dunn, 1970) and total proteins, by the method of Lowry et al. (1951).

\subsection{Water quality monitoring}

The following variables were weekly monitored throughout the experiment: temperature (precision $\pm 0.5^{\circ} \mathrm{C}$ ), pH (Jenco Model $6350 \mathrm{pH}$ meter, precision \pm 0.01 ), dissolved oxygen (Digital Oxygen Meter, precision $\pm 0.01 \mathrm{mg} / \mathrm{L}$ ), ammonium (Wiener ${ }^{\circledR}$ kit), nitrites and total hardness (Acuanalítica ${ }^{\circledR}$ kits, for low detection range). Besides, a sample of $20 \mathrm{~mL}$ of water culture was taken every $15 \mathrm{~d}$ from each aquarium, to determine chlorophyll $a$ concentration, following the same procedure indicated above for biofilm.

\subsection{Statistical analysis}

Biofilm dry weight, chlorophyll $a$ concentration, as well as water quality parameters were analyzed by a two way-ANOVA, taking experimental group and time of sampling as factors. Lilliefors and Levene tests were used for checking normality and homogeneity of variance, respectively. To analyze survival, SGR, biomass or energetic reserve levels of juveniles at the end of the experiment, a one wayANOVA was used. Angular transformation was used for survival. When pertinent, Tukey test was used for multiple comparisons of means. Both data normality and homogeneity of variances were always checked. A 5\% significance level was always considered (Sokal and Rohlf, 1995).

\section{Results}

\subsection{Biofilm}

For both early and advanced juveniles, no significant difference ( $p>0.05$ ) was observed in the dry weight of biofilm adhered to plastic sheets, neither between groups $\mathrm{B}$ and $\mathrm{B}+\mathrm{F}$, nor among times of sampling (Fig. 1). Concerning chlorophyll a concentration, no significant $(p>0.05)$ differences were found throughout the assay between $B$ and $B+F$ groups, but significant $(p<0.05)$ differences were seen among sampling time, depending on the kind of juveniles. For early juveniles, a significant $(\mathrm{p}<0.05)$ increase of chlorophyll $a$ concentration was seen at the first week, gradually decreasing toward the end of the experiment (Fig. 1). For advanced juveniles, though, a significant $(\mathrm{p}<0.05)$ decrease occurred from day 0 to day 15 (Fig. 1 ).

Identification of the micro-organisms presented in the biofilm adhered to plastic nets provided to groups $\mathrm{B}$ and $\mathrm{B}+\mathrm{F}$ is indicated in Table 1, for both early and advanced juveniles. Main microorganisms identified in most samples were: both filamentous and aggregated cyanobacteria (such as Phormidium sp and Aphanocapsa sp), pennate diatoms (such as Achnantidiun exiguum, Nitzschia spp, Navicula spp and Gomphonema spp), chlorophytas (Oedogonium spp.), xantophylas (Characiopsis sp), ciliates (such as Vorticella sp, Euplotes $\mathrm{sp}$, Coleps $\mathrm{sp}$ ), flagellates, rotifers and nematods. No microorganisms were found in any sample taken from the control plastic sheets placed on the aquaria of group $\mathrm{F}$.

\subsection{Juveniles}

\subsubsection{Survival and growth}

Results of both survival and growth of juveniles are shown in Table 2. For both groups of juveniles, survival was significantly $(\mathrm{p}<0.05)$ higher in groups with biofilm $(\mathrm{B}$ and $\mathrm{B}+\mathrm{F})$ than in group fed with formulated feed $(\mathrm{F})$, in which survival was relatively low (40\% and $60 \%$ in early and advanced juveniles, respectively, Table 2). For early juveniles, SGR was significantly $(\mathrm{p}<0.05)$ higher

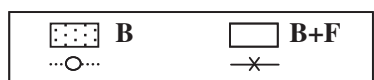

\section{Early juveniles}
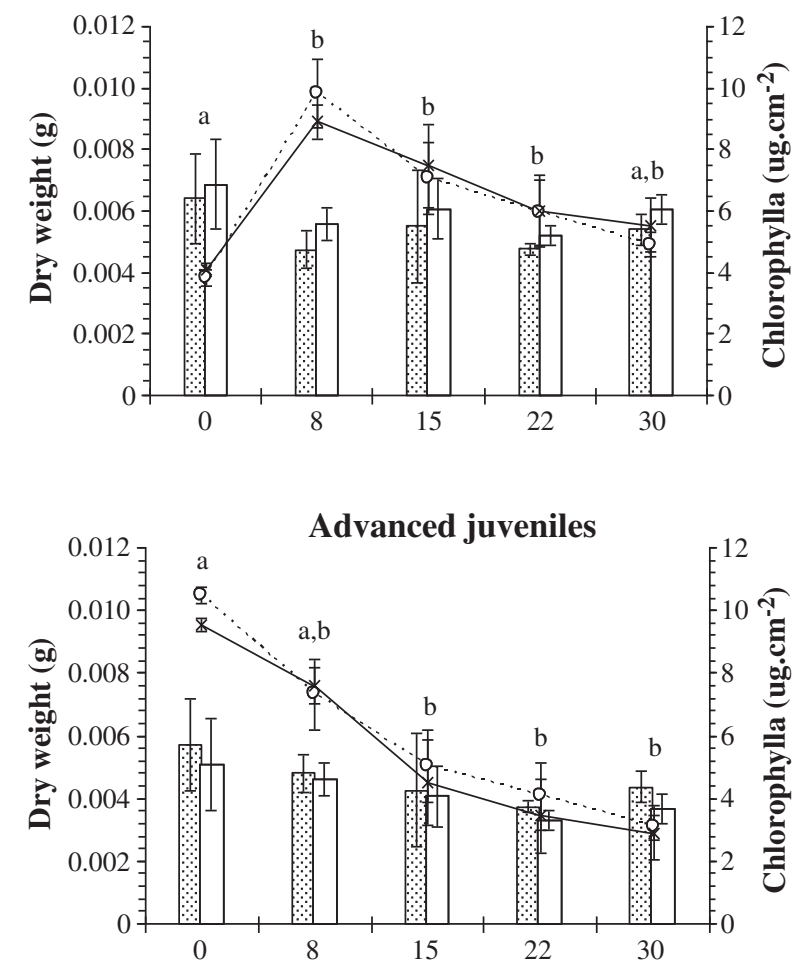

Time (days)

Fig. 1. Mean values $( \pm \mathrm{SE})$ of both dry weight (bars) and chlorophyll $a$ (lines) of the biofilm adhered to artificial substrates, throughout the 30-d experiment. Experimental groups $(B, B+F)$ as defined in Table 1. No significant $(p>0.05)$ differences were found for dry weight. Different letters indicate significant $(\mathrm{p}<0.05)$ differences in chlorophyll $a$ among sampling times, for both kinds of juveniles.

in the groups receiving formulated feed $(\mathrm{B}+\mathrm{F}$ and $\mathrm{F})$ than in the group only receiving biofilm (B), while no significant differences ( $p>0.05)$ were detected for the advanced juveniles. Biomass showed the highest value in the $\mathrm{B}+\mathrm{F}$ group, compared to the remaining groups. For early juveniles, significant differences $(p<0.05)$ were detected between $\mathrm{B}+\mathrm{F}$ and any of the remaining groups, while for advanced juveniles significant differences $(\mathrm{p}<0.05)$ were only detected between $\mathrm{B}+\mathrm{F}$ and $\mathrm{F}$ (Table 2 ).

\subsubsection{Stomach content}

Stomach samples taken from the groups B and B $+\mathrm{F}$ showed micro-organism items very similar to those detected in the biofilm provided to the same groups, indicating that both early and advanced juveniles had fed on it (Table 1). However, no nematodes were detected in the stomach of early juveniles, and also in only $33 \%$ $(\mathrm{N}=5)$ of those stomachs some rotifers were detected; while both items were found in the stomach of all advanced juveniles. Stomach taken from the F group showed some kind of micro-organisms, such as filamentous cyanobacteria, pennate diatoms, chlorophytes and xantophytes (Table 1 ), but in a very lower extent than that observed in groups $\mathrm{B}$ and $\mathrm{B}+\mathrm{F}$.

\subsubsection{Energetic reserves}

No significant $(\mathrm{p}>0.05)$ differences among groups of early juveniles were detected in either hepatopancreatic or muscle glycogen 
Table 1

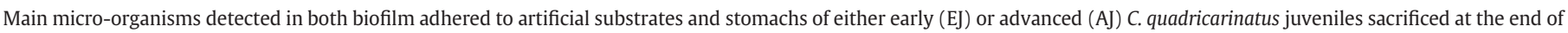

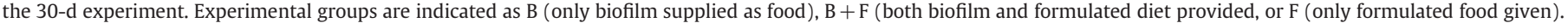
$(-)$ : absence, $(+)$ : low frequency, $(++)$ : median frequency, $(+++)$ : high frequency.

\begin{tabular}{|c|c|c|c|c|c|c|c|c|c|c|c|c|c|c|c|c|}
\hline \multirow[t]{3}{*}{ Division } & \multirow[t]{3}{*}{ Family } & \multirow[t]{3}{*}{ Gender/specie } & \multirow[t]{3}{*}{$\begin{array}{l}\text { Juvenile } \\
\text { stage }\end{array}$} & \multicolumn{10}{|c|}{ Presence in biofilm at different sampling days } & \multicolumn{3}{|c|}{$\begin{array}{l}\text { Presence in } \\
\text { stomach }\end{array}$} \\
\hline & & & & \multicolumn{5}{|l|}{ B } & \multicolumn{5}{|c|}{$\mathrm{B}+\mathrm{F}$} & \multirow{2}{*}{$\frac{\mathrm{B}}{30}$} & \multirow{2}{*}{$\frac{B+F}{30}$} & \multirow{2}{*}{$\frac{F}{30}$} \\
\hline & & & & 0 & 8 & 15 & 22 & 30 & 0 & 8 & 15 & 22 & 30 & & & \\
\hline \multirow[t]{8}{*}{ Cyanophyta } & \multirow[t]{6}{*}{ Oscillatoriaceae } & \multirow[t]{2}{*}{ Phormidium sp. } & EJ & ++ & ++ & ++ & ++ & ++ & ++ & ++ & ++ & ++ & ++ & + & ++ & + \\
\hline & & & AJ & ++ & + & - & + & + & ++ & ++ & + & + & + & $\begin{array}{l}+ \\
+\end{array}$ & ++ & + \\
\hline & & \multirow[t]{2}{*}{ Plectonema sp. } & EJ & - & - & - & + & - & - & - & - & + & + & - & - & - \\
\hline & & & AJ & - & - & - & + & + & - & - & - & + & - & + & - & - \\
\hline & & \multirow[t]{2}{*}{ Oscillatoria sp. } & EJ & - & - & - & - & - & - & + & - & - & - & - & - & - \\
\hline & & & AJ & - & + & - & - & - & - & - & - & - & - & - & - & - \\
\hline & \multirow[t]{2}{*}{ Chroococcales } & \multirow[t]{2}{*}{ Aphanocapsa sp. } & EJ & + & + & + & + & + & + & + & + & + & + & + & + & - \\
\hline & & & AJ & + & + & - & + & + & + & - & + & + & - & + & + & - \\
\hline \multirow[t]{14}{*}{ Bacillariophyta } & \multirow{12}{*}{ Bacillariophyceae } & Cocconeis spp. & EJ & + & - & - & - & - & + & - & - & - & + & - & - & - \\
\hline & & & AJ & + & - & - & - & - & + & - & - & - & - & - & - & - \\
\hline & & Gomphonema spp. & EJ & + & + & + & - & + & + & + & + & - & + & + & + & - \\
\hline & & & AJ & + & - & - & + & + & + & - & + & + & + & + & + & + \\
\hline & & Hantzchia spp. & EJ & + & + & - & - & + & + & + & - & - & + & - & - & - \\
\hline & & & AJ & + & - & - & - & + & + & + & - & - & + & - & - & - \\
\hline & & Navicula spp. & EJ & + & - & - & + & + & + & - & + & - & + & - & - & - \\
\hline & & & AJ & + & + & + & + & + & - & + & + & + & - & + & + & - \\
\hline & & Nitzschia spp. & EJ & + & + & + & + & + & + & + & + & + & + & + & + & - \\
\hline & & & $\mathrm{AJ}$ & + & + & + & + & + & - & - & + & + & - & + & - & - \\
\hline & & $\begin{array}{l}\text { Achnanthidiun } \\
\text { exiguum }\end{array}$ & EJ & ++ & ++ & ++ & + & + & ++ & ++ & ++ & + & + & $\begin{array}{l}+ \\
+\end{array}$ & ++ & + \\
\hline & & & $\mathrm{AJ}$ & ++ & ++ & + & + & + & ++ & ++ & ++ & + & + & $\begin{array}{l}+ \\
+\end{array}$ & ++ & + \\
\hline & Coscinodiscophyceae & Cyclotella spp. & EJ & - & - & - & - & - & + & - & - & - & - & - & - & - \\
\hline & & & AJ & + & - & - & - & - & - & - & - & - & - & - & - & - \\
\hline Chlorophyta & Chlorophyceae & Oedogonium spp. & EJ & ++ & ++ & ++ & ++ & ++ & ++ & ++ & ++ & ++ & ++ & + & ++ & + \\
\hline & & & $\mathrm{AJ}$ & ++ & ++ & ++ & ++ & ++ & ++ & ++ & ++ & ++ & ++ & + & ++ & + \\
\hline Xantophyta & Characiopsidaceae & Characiopsis sp. & EJ & $\begin{array}{l}++ \\
+\end{array}$ & $\begin{array}{l}++ \\
+\end{array}$ & $\begin{array}{l}++ \\
+\end{array}$ & $\begin{array}{l}++ \\
+\end{array}$ & $\begin{array}{l}++ \\
+\end{array}$ & $\begin{array}{l}++ \\
+\end{array}$ & $\begin{array}{l}++ \\
+\end{array}$ & $\begin{array}{l}++ \\
+\end{array}$ & $\begin{array}{l}++ \\
+\end{array}$ & $\begin{array}{l}++ \\
+\end{array}$ & $\begin{array}{l}+ \\
+\end{array}$ & ++ & + \\
\hline & & & AJ & ++ & ++ & ++ & ++ & ++ & ++ & ++ & ++ & ++ & ++ & + & ++ & + \\
\hline & & & & + & + & + & + & + & + & + & + & + & + & + & & \\
\hline Mastigophora & & & EJ & ++ & ++ & + & + & + & ++ & ++ & + & + & + & - & - & - \\
\hline (flagellates) & & & AJ & ++ & ++ & ++ & + & + & ++ & ++ & ++ & + & + & - & - & - \\
\hline Ciliophora (ciliates) & Vorticellidae & Vorticella sp. & EJ & - & + & + & + & ++ & - & + & + & + & ++ & - & - & - \\
\hline & & & $\mathrm{AJ}$ & - & + & + & + & ++ & - & + & + & ++ & ++ & - & - & - \\
\hline & Euplotidae & Euplotes sp. & EJ & - & + & + & + & ++ & - & + & + & + & ++ & - & - & - \\
\hline & & & $\mathrm{AJ}$ & - & + & + & + & ++ & - & + & + & + & ++ & - & - & - \\
\hline & Colepsidae & Coleps sp. & EJ & - & + & + & + & + & - & + & + & + & + & - & - & - \\
\hline & & & AJ & - & + & + & + & + & - & + & + & + & + & - & - & - \\
\hline Rotifera & & & EJ & - & - & + & + & + & - & - & + & + & + & + & + & - \\
\hline & & & AJ & - & + & + & + & + & - & + & + & + & + & + & + & - \\
\hline Nematoda & & & EJ & - & - & + & + & + & - & - & + & + & + & - & - & - \\
\hline & & & AJ & - & - & + & + & + & - & - & + & + & + & + & + & - \\
\hline
\end{tabular}

level (Fig. 2A). For advanced juveniles, though, glycogen level in hepatopancreas was significantly $(\mathrm{p}<0.05)$ higher in group $\mathrm{F}$ than in group $B$, but no differences $(p>0.05)$ were detected between $F$ and

\section{Table 2}

Mean values $( \pm$ SE) of specific growth rate (SGR), total biomass and survival of both early (EJ) and advanced (AJ) C. quadricarinatus juveniles at the end of the 30-d experiment. Experimental groups (B, B + F and F) as defined in Table 1. Different letters indicate significant $(\mathrm{p}<0.05)$ differences, for each juvenile stage.

\begin{tabular}{lllll}
\hline Variable & \multirow{2}{*}{$\begin{array}{l}\text { Juvenile } \\
\text { stage }\end{array}$} & \multicolumn{4}{l}{ Experimental group } \\
\cline { 3 - 5 } & & $\mathrm{B}$ & $\mathrm{B}+\mathrm{F}$ & $\mathrm{F}$ \\
\hline Survival (\%) & EJ & $81.4 \pm 7.4^{\mathrm{a}}$ & $90.3 \pm 3.7^{\mathrm{a}}$ & $44.5 \pm 7.7^{\mathrm{b}}$ \\
& AJ & $90.7 \pm 1.9^{\mathrm{a}}$ & $79.6 \pm 1.9^{\mathrm{a}}$ & $59.3 \pm 8.1^{\mathrm{b}}$ \\
SGR $(\% /$ day) & EJ & $2.5 \pm 0.1^{\mathrm{a}}$ & $4.4 \pm 0.1^{\mathrm{b}}$ & $3.7 \pm 0.4^{\mathrm{b}}$ \\
& AJ & $0.6 \pm 0.2^{\mathrm{a}}$ & $1.5 \pm 0.2^{\mathrm{a}}$ & $1.2 \pm 0.4^{\mathrm{a}}$ \\
Biomass $\left(\mathrm{g} / \mathrm{m}^{2}\right)$ & EJ & $12.8 \pm 1.4^{\mathrm{a}}$ & $32.5 \pm 2.1^{\mathrm{b}}$ & $14.5 \pm 2.7^{\mathrm{a}}$ \\
& AJ & $68.4 \pm 2.6^{\mathrm{a}, \mathrm{b}}$ & $82.2 \pm 4.8^{\mathrm{b}}$ & $57.8 \pm 3.7^{\mathrm{a}}$ \\
\hline
\end{tabular}

$B+F$ groups. No significant $(p>0.05)$ differences were seen concerning muscle glycogen level of advanced juveniles (Fig. 2A).

For both groups of juveniles, hepatopancreatic lipid levels were significantly $(\mathrm{p}<0.05)$ lower in the B group, compared to either $\mathrm{F}$ or $B+F$, which did not differ $(p>0.05)$ from each other. No significant ( $p>0.05$ ) differences were found in muscle lipid levels (Fig. 2B). Protein level in both hepatopancreas and muscle neither differ $(p>0.05)$ among groups, for both early and advanced juveniles (Fig. 2C).

\subsection{Water quality}

Temperature ranged between 22 and $28{ }^{\circ} \mathrm{C}$ in all groups throughout the experiment, for both early and advanced juveniles. Dissolved oxygen, $\mathrm{pH}$ and total hardness did not show any difference $(\mathrm{p}>0.05)$ between $\mathrm{B}$ and $\mathrm{B}+\mathrm{F}$ treatments during the experiment, for both kinds of juveniles (Figs. 3 and 4). Instead, dissolved oxygen and $\mathrm{pH}$ values detected after the first week in the F group were significantly 


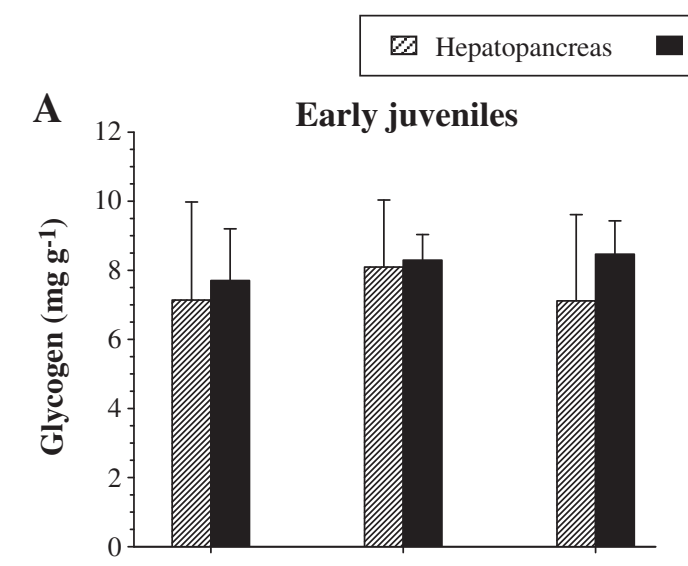

Abdominal muscle
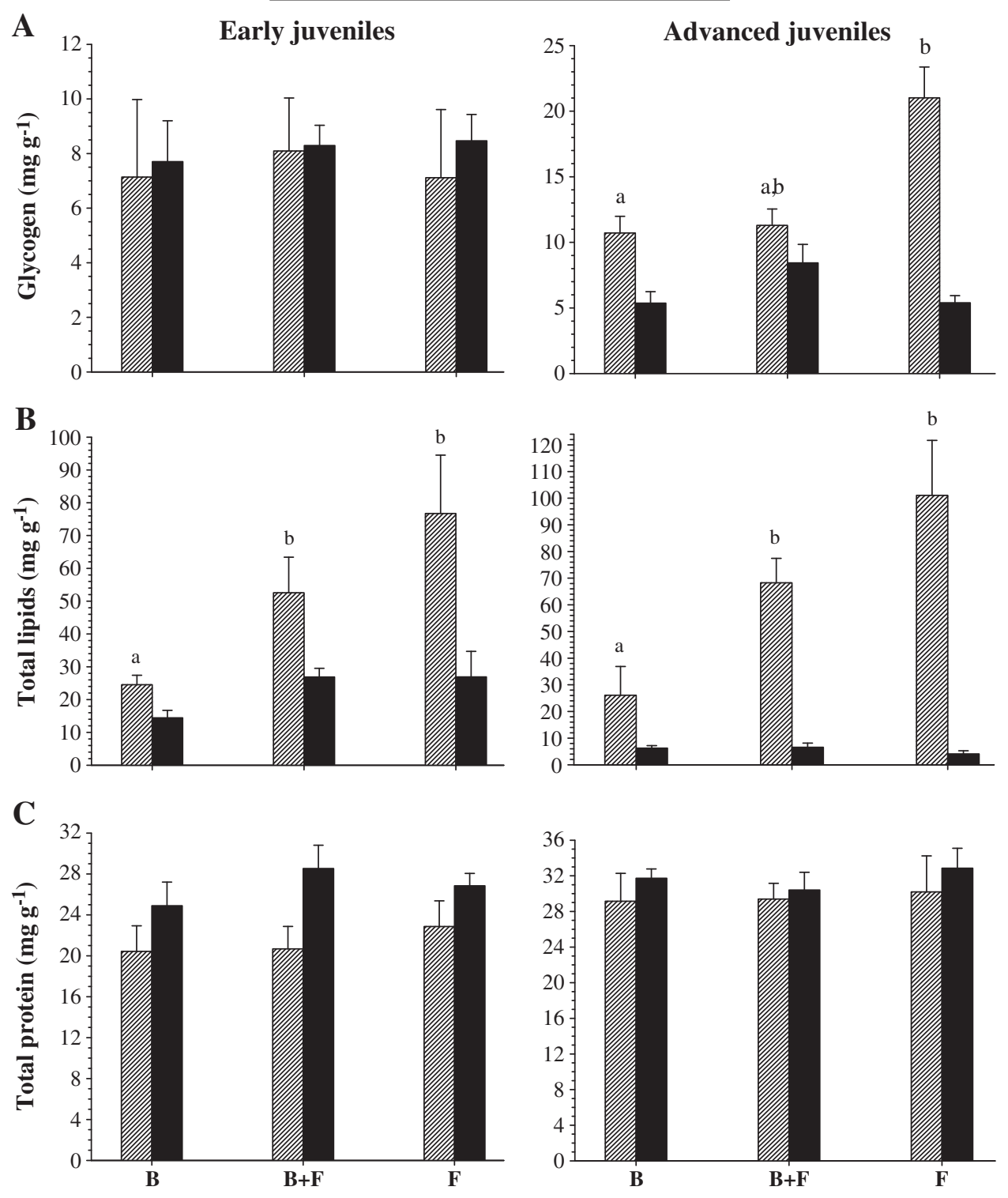

Experimental group

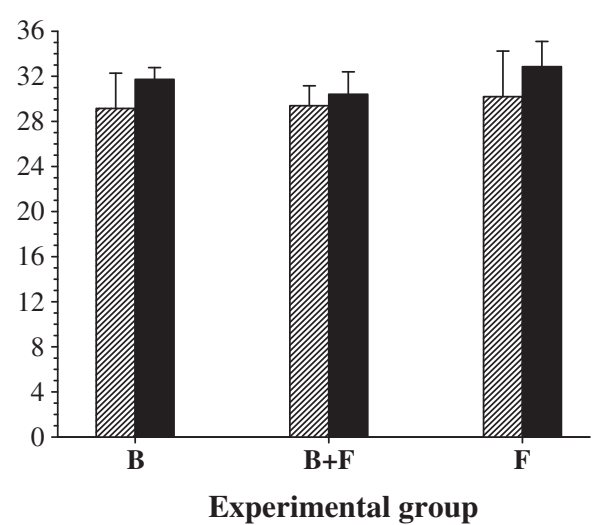

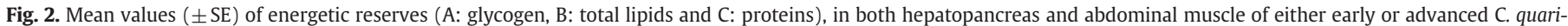

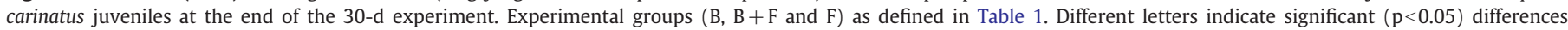
among experimental groups, for each tissue.

$(p<0.05)$ lower than values observed in the remaining groups; while hardness seen by day 15 th was significantly $(\mathrm{p}<0.05)$ higher in the $\mathrm{F}$ group compared to B or B $+\mathrm{F}$ group (Figs. 3 and 4 ).

No significant difference $(p>0.05)$ were observed in the ammonium and nitrite concentrations neither between $B$ and $B+F$ treatments nor among times of sampling, for any kind of juveniles (Figs. 3 and 4), being the corresponding values below the recommended limits for culturing of the studied species (Boyd, 1982; Jones, 1997). However, during the first two weeks the F group of early juveniles showed a significant $(\mathrm{p}<0.05)$ increase of both ammonium and nitrite concentrations, with respect to the other two groups, reaching by day 15 th values exceeding the recommended limit for culture of the studied species (Fig. 3). Besides, dissolved oxygen showed a significant $(p<0.05)$ decrease in the $\mathrm{F}$ group of early juveniles after the first week, together with a marked increase in mortality (near 25\%). This fact led us to completely exchange the water of the aquaria at day 22th, to avoid further mortality. After water replacement, levels of ammonium, nitrite and hardness decreased near initial values. However, at the end of the experiment nitrite concentration increased significantly $(\mathrm{p}<0.05)$ in the $\mathrm{F}$ group, reaching again the value recorded at day 15 th (Fig. 3).

For advanced juveniles, the F group showed a significant $(\mathrm{p}<0.05)$ increment of ammonium concentration by the first week of the experiment, with respect to the remaining groups, exceeding the recommended limit. By the third week, ammonium levels returned to values similar to the initial one, but at day 30th a new significant $(\mathrm{p}<0.05)$ increment was observed (Fig. 4). Nitrite concentration reached its maximum value $(\mathrm{p}<0.05)$ at day 15 and up to the end of the assay (Fig. 4).

Finally, the concentration of chlorophyll $a$ in the culture water, for both kinds of juveniles, showed a gradual increment during the experiment. This increment was statistically significant just at the end 


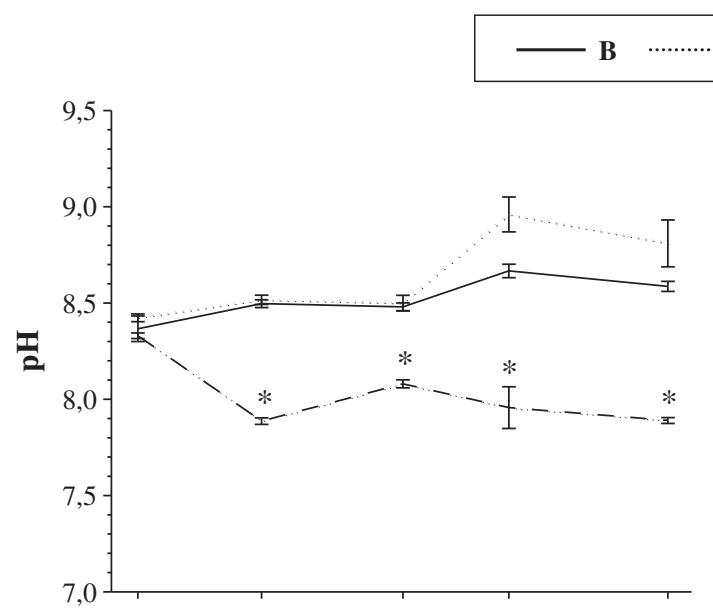

$$
\mathbf{B}+\mathbf{F}-\cdots-\mathbf{F}
$$
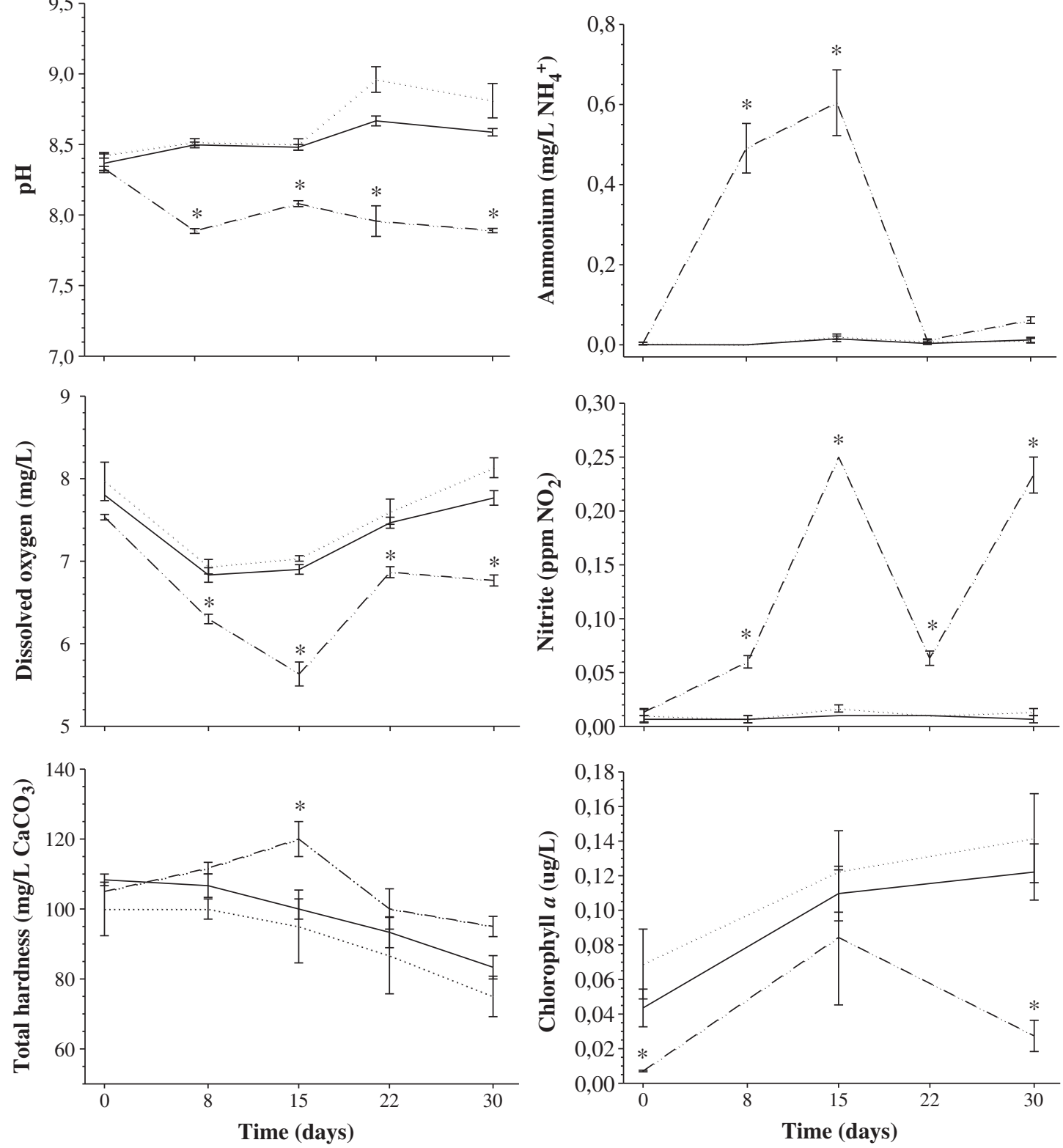

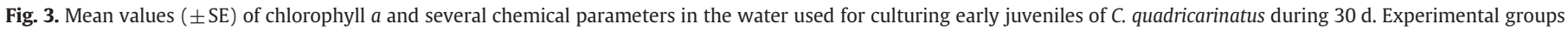

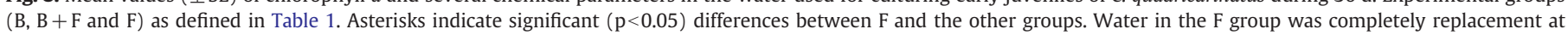
day 22th (see text).

of the experiment, with respect to the initial value, but only for the groups B and B +F (Figs. 3 and 4). The decrease of chlorophyll $a$ seen in the F group of early juveniles was correlated to the water replacement made at day 22nd.

\section{Discussion}

For early juveniles of $C$. quadricarinatus, formulated diet yielded a growth rate (SGR) higher than produced by biofilm as a single diet. However, survival was significantly improved by the presence of biofilm. Moreover, the best values of either SGR or survival were seen in the combination of both formulated food and biofilm as food sources. Correspondingly, the highest value of biomass (an integrative index of both survival and growth) was seen in the later group, at the end of the experiment. Juveniles feeding on both sources would be incorporating a broader spectrum of nutrients, while a high survival would be likely favored by a better water quality associated to the presence of biofilm, as discussed below. Advanced C. quadricarinatus juveniles showed a similar trend than early juveniles concerning survival, but growth did not show significant variations among treatments, probably due to the relatively high within-groups variability (standard errors higher than mean by $30 \%$, Table 2 ).

The only previous report concerning biofilm effects on crayfish species, made on C. destructor by Jones and Thanuthong (2002), showed that early juveniles fed on both pellet food and biofilm, grew better than those juveniles only fed with pellets. Shrimp and prawn species, though, have received more attention to this respect. For instance, incorporation of biofilm to the intensive culture of both juveniles and post-larvae of Litopenaeus vannamei (Bratvold and Browdy, 2001; Moss and Moss, 2004; Zhang et al., 2010), and also juveniles of the shrimp Penaeus monodon (Stuart et al., 2006), improved both weight gain and survival. Biofilm also showed to 


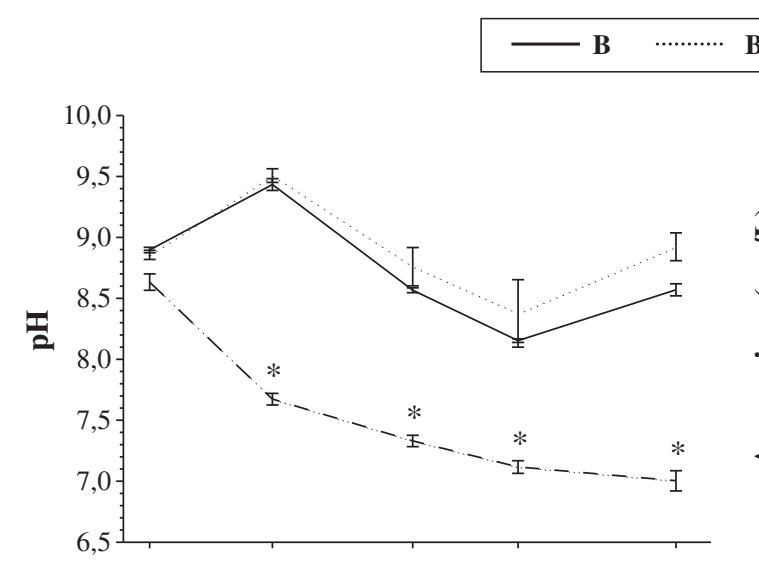

$$
\mathbf{B}+\mathbf{F}-\cdots-\mathbf{F}
$$
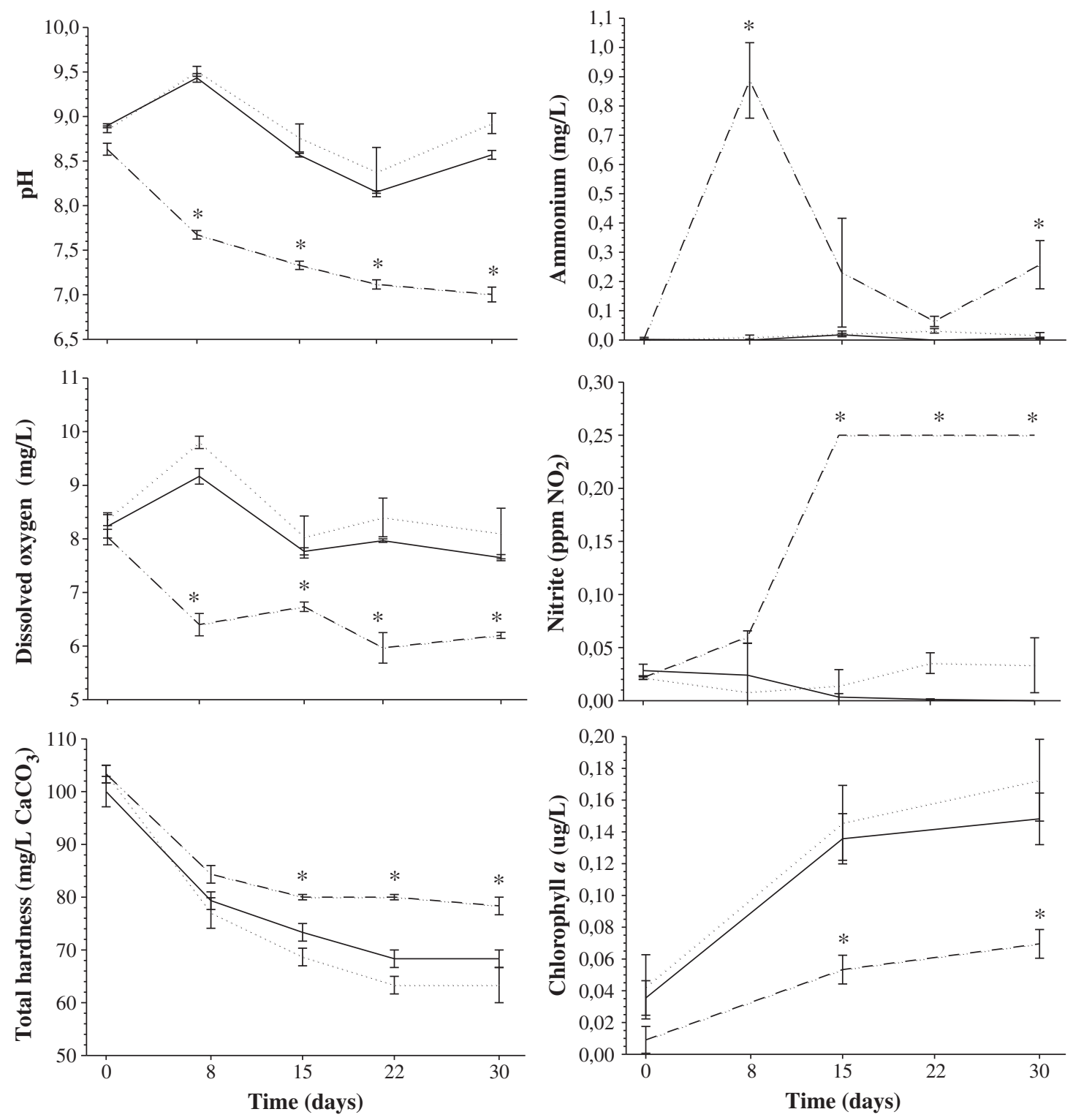

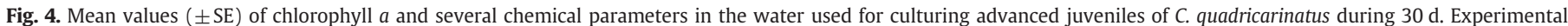
groups $(B, B+F$ and $F)$ as defined in Table 1. Asterisks indicate significant $(p<0.05)$ differences between $F$ and the other groups.

contribute with several additional nutrients to post-larvae of Penaeus esculentus, reared at high densities (Burford et al., 2004). This kind of benefits was also found in other species of high economic value, such as the prawn Macrobrachium rosenbergii (Tidwell et al., 1998) and the shrimp Farfantepenaeus paulensis (Ballester et al., 2007).

Although total dry weight of biofilm remained constant in all the experimental groups where it was assayed, chlorophyll $a$ concentration decreased throughout the experiment. During the first two weeks of the assay, autotrophic organisms like chlorophytes, xanthophytas, diatoms, flagellates and cyanobacteria were observed, probably contributing to the decrease observed in nitrogenous compounds in water. However, during the second half of the experiment some heterotrophic groups (mainly cilliates, nematodes and rotifers) proliferated, probably grazing on the autotrophic groups and therefore causing the decrease in chlorophyll $a$ observed during this period. According to Da Silva et al. (2009) and Whal (1989), biofilm is formed following a settling pattern, being the relatively high size microorganisms (such as ciliates, nematodes and rotifers) the items colonizing biofilm during its advanced stage of formation. On the other hand, the gradual increment in chlorophyll $a$ observed in the culture water throughout the experiment, mainly in the groups provided with biofilm, could be likely due to the proliferation of autotrophic organisms in the column water from the biofilm already formed, as suggested in previous studies on biofilm systems (Decamp et al., 2002; Moss and Moss, 2004; Thompson et al., 1999).

Both early and advanced juveniles of $C$. quadricarinatus were seen actively grazing on the biofilm formed on the artificial substrates used. From the analysis of stomach content, the main consumed items were chlorophytes, xanthophytas, diatoms, filamentous and aggregated cyanobacteria; only in stomach of some bigger early juveniles rotifers were also seen, but no nematodes were found. Instead, advanced juveniles were able to ingest all the items above mentioned, including nematodes and rotifers, which were found in the stomach of all these juveniles. The development of all the feeding apparatus (such as mandibular appendices and gastric mill), needed for eating and processing relatively big size zooplankton, seems to gradually 
complete during the early juvenile instars of $C$. quadricarinatus (LoyaJavellana et al., 1994). Some studies found that highest growth rate of F. paulensis juveniles was related to the consumption of biofilm colonized by nematodes, a substantial source of nutrients for shrimps (Ballester et al., 2007; Pissetti, 2005). The presence of certain autotrophic organisms in the stomach of some juveniles of the F group could be the consequence of the proliferation of such micro-organisms in water, probably favored by the accumulation of organic matter due to dead animals or exuviae, as seen in previous studies (Decamp et al., 2002; Moss and Moss, 2004).

Total lipid levels, determined at the end of the assay, showed a higher accumulation of lipid in the hepatopancreas of both early and advanced juveniles fed on formulated diet, alone or in combination with biofilm. In addition, a higher glycogen level was observed in advanced juveniles fed with that food. The hepatopancreas of crustaceans is in fact the main storage organ for both lipids and carbohydrates (Hernández-Vergara et al., 2003; Verri et al., 2001). The relatively high caloric value of the commercial food employed (254 kcal/100 g, Chaulet et al., 2008) could be therefore explaining the higher caloric reserve levels seen in the hepatopancreas of juveniles fed with formulated food. Nevertheless, these levels of energetic reserve (expressed as $\mathrm{mg} / \mathrm{g}$ of tissue) did not show a clear correlation with the growth index calculated (SGR): as mentioned before, the maximum value of SGR, for both kinds of juveniles, was seen in the $\mathrm{B}+\mathrm{F}$ group, while maximum values of lipid reserves were found in juveniles only fed with formulated food (F group). These results are suggesting that factors other than the level of energetic reserves (such as vitamins, prebiotics and other micronutrients) are involved in growing of juveniles, and also that such factors are related to biofilm consumption. Consumption of plant material has been previously suggested to enhance growth of $C$. quadricarinatus juveniles (Jones, 1997). Interestingly, protein levels in both hepatopancreas and muscle were similar in all groups of juveniles, indicating that no serious nutritional deficit seemed to be occurred in such juveniles that only had biofilm as food source.

Several studies reported high protein level for biofilm microorganisms, i.e., ranging from 20 to $40 \%$ (dry weight basis) in diatoms (Martínez-Fernández et al., 2006; Renaud et al., 1999), to more than $50 \%$ (dry weight basis) in nematodes (Schlechtriem et al., 2004). Besides, several micro-organisms of biofilm present a high proportion of amino-acids, vitamins, cartenoids, esteroids and polyunsaturated fatty acids, these latter intensively produced by cyanobacteria, flagellates, ciliates and nematodes (Meyers and Latscha, 1997; Schlechtriem et al., 2004; Zhukova and Kharlamenko, 1999). Burford et al. (2004), by using stable isotopes, have reported that both carbon and nitrogenous coming from micro-organisms of biofilm were assimilated by shrimp post-larvae under intensive culture, contributing in a great extent $(39-53 \%)$ to their nutritional requirements. With the same technique, Abreu et al. (2007) observed that micro-organisms of biofilm can contribute with $49 \%$ of carbon and $70 \%$ of the nitrogenous needed for growing of $F$. paulensis early juveniles. Avnimelech (2000) determined that micro-organisms presented in culture tanks increased the efficiency to protein conversion around $45 \%$, by incorporating inorganic nitrogenous dissolved in water to microbial protein, which is further ingested by cultured animals, therefore reducing the use of formulated food.

A clear benefit of biofilm to both survival and growth of cultured species is related to water quality. Several bacteria and microalgae presented in biofilm are able to actively uptake ammonium and other nitrogenous waste, to synthesize protein that can be consumed by either fish or crustaceans, therefore contributing to both water quality maintenance and nutrition of cultured animals (Azim et al., 2001; Bratvold and Browdy, 2001; Ramesh et al., 1999). Other studies have shown that nitrogenous uptake by biofilm micro-organisms can help reduce the proliferation of pathogen bacteria in cultures (Alabi et al., 1999; Thompson et al., 2002). In the current study, both ammonium and nitrite concentrations were maintained at a very low and constant level in the aquaria where biofilm was added, while those aquaria only receiving formulated food showed increased levels of both toxic metabolites, frequently above the permissible levels for aquaculture. These relatively high levels were associated, especially for early juveniles, to an increased mortality. Therefore, obtained results strongly suggest that absorption and/or transformation of nitrogenous waste compounds by biofilm micro-organisms greatly improve the survival of juveniles of the studied species

According to Thompson et al. (2002) biofilm developed on the wall of shrimp culture tanks was able to maintain the water concentration of both ammonium and phosphorous at low levels, especially once chlorophyll $a$ reaches values around $5 \mu \mathrm{g} / \mathrm{cm}^{2}$; this chlorophyll mainly corresponding to both pennate diatoms and cyanobacteria presented in biofilm. For both kinds of $C$. quadricarinatus juveniles, chlorophyll $a$ in biofilm ranged from 4 to $10 \mu \mathrm{g} / \mathrm{cm}^{2}$, in correlation with low levels of both ammonium and nitrite in water. On the contrary, in those aquaria with no biofilm added, high and fluctuating levels of nitrogenous waste were verified. These later aquaria, compared to those provided with biofilm, also showed lower values of both $\mathrm{pH}$ and dissolved oxygen, as expected from a weak development of an autotrophic community helping to regulate such critical variables. In this sense, the gradual increment in chlorophyll $a$ levels seen in the water column of group F could indicate the presence of some autotrophic micro-organisms in such compartment, but their contribution to the control of nitrogenous waste was not certainly so efficient as that of micro-organisms associated to the biofilm developed in groups $\mathrm{B}$ and $\mathrm{B}+\mathrm{F}$. However, both $\mathrm{pH}$ and dissolved oxygen in F groups showed moderate fluctuations, in all cases below the recommended limits for the studied species (Jones, 1997; Masser and Rouse, 1997).

\section{Conclusion}

We conclude that the addition of biofilm to culture of $C$. quadricarinatus juveniles represents a clear advantage for both survival and growth of animals. Biofilm is clearly involved in the maintenance of water quality (essential for a good survival), and perhaps also as complementary food source, therefore improving the growth of juveniles, especially early ones. By using biofilm in a zero water exchange system, a significant reduction in the cost of production could also be attained.

\section{Acknowledgements}

Authors wish to help the financial support given by CAPES (Brazil) and MINCYT (Argentina). Grants from UBACYT program (X241) and from CNPq were also used to support this study.

\section{References}

Abreu, P.C., Ballester, E.C., Odebrecht, C., Wasielesky Jr., W., Cavalli, R.O., Granéli, W., Anésio, A.M., 2007. Importance of biofilm as food source for shrimp (Farfantepenaeus paulensis) evaluated by stable isotopes (d13C and d15N). Journal of Experimental Marine Biology and Ecology 347, 88-96.

Alabi, A.G., Cob, Z.C., Jones, D.A., Latchford, J.W., 1999. Influence of algal exudates and bacteria on growth and survival of white shrimp larvae fed entirely on microencapsulated diets. Aquaculture International 7, 137-158.

Austin, C.M., Jones, P.L., Stagnitti, F., Mitchell, B.D., 1997. Response of the yabby, Cherax destructor Clark, to natural and artificial diets: phenotypic variation in juvenile growth. Aquaculture 149, 39-46.

Avnimelech, Y., 2000. Protein utilization in aquaculture systems. International Conference Aqua 2000, European Aquaculture Society, May 2-6., Nice, France, p. 41.

Azim, M.E. Wahab, M.A., Van Dam, A.A., Beveridge, M.C., Verdegem, M.C. 2001. The potential of periphyton-based culture of two Indian major carps, rohu Labeo rohita (Hamilton) and gonia Labeo gonius (Linnaeus). Aquaculture Research 32, 209-216.

Ballester, E.C., Wasielesky Jr., W., Cavalli, R.O., Abreu, P.C., 2007. Nursery of the pink shrimp Farfantepenaeus paulensis in cages with artificial substrates: biofilm composition and shrimp performance. Aquaculture 269, 355-362.

Boyd, C.E., 1982. Water quality Management of Pond Fish Culture. Elsvier Scientific Publishing Company, Amsterdam. 
Bratvold, D., Browdy, C.L., 2001. Effects of sand sediment and vertical surfaces (aquamats) on production, water quality, and microbial ecology in an intensive Litopenaeus vannamei culture system. Aquaculture 195, 81-94.

Burford, M.A., Smith, D.M., Tarbrett, S.J., Coman, F.E., Thompson, P.J., Barllay, M.C., Toscas, P.J., 2004. The effect of dietary protein on the growth and survival of the shrimp Penaeus monodon in outdoor tanks. Aquaculture Nutrition 10, 15-23.

Canter-Lund, H., Lund, J.W.G., 1995. Freshwater Algae: Their Microscopic World Explored. Biopress Limited, Bristol.

Campaña-Torres, A., Martínez-Córdova, L.R., Villarreal-Colmenares, H., Civera-Cerecedo, R., 2006. Carbohydrate and lipid digestibility of animal and vegetal ingredients and diets for juvenile Australian redclaw crayfish, Cherax quadricarinatus. Aquaculture Nutrition 12, 103-109.

Chaulet, A., López-Greco, L.S., Rodríguez, E.M., 2008. Somatic growth of juvenile freshwater crayfish Cherax quadricarinatus fed diets supplemented with ecdysone. In: Possebon, J.E., Scorvo, J.D., Sampaio, L.A., Cavalli, R. (Eds.), Tópicos Especiais em Biologia Aquática e Aqüicultura II, Brazil, pp. 305-313.

Cortés-Jacinto, E., Villarreal-Colmenares, H., Civera-Cerecedo, R., Martínez-Córdova, L.R., 2003. Effect of dietary protein level on growth and survival of juvenile freshwater crayfish Cherax quadricarinatus (Decapoda: Parastacidae). Aquaculture Nutrition 9, 207-213.

Da Cunha, A.M., 1913. Contribuição para o conhecimento da fauna de protozoarios do Brazil. Memórias do Instituto Oswaldo Cruz 5, 101-122.

Da Silva, F.C., Ballester, E.C., Montserrat, J., Geracitano, L., Wasielesky Jr., W., Abreu, P.C., 2009. Contribution of microorganisms to the biofilm nutritional quality: protein and lipid contents. Aquaculture Nutrition 14, 507-514.

Decamp, O., Conquest, L., Forster, I., Tacon, A.G.J., 2002. The nutrition and feeding of marine shrimp within zero-water exchange aquaculture production systems: role of eukaryotic microorganisms. In: Lee, C.S., O'Brien, P. (Eds.), Microbial approaches to aquatic nutrition within environmentally sound aquaculture production systems. World Aquaculture Society, Baton Rouge, Louisiana, pp. 79-84.

Decho, A.W., 1990. Microbial exopolymer secretions in ocean environments: their role (s) in food webs and marine processes. Oceanography and Marine Biology: An Annual Review 28, 73-153.

Folch, J., Lees, M., Stanley, G., 1957. A simple method for isolation and purification of total lipids from animal tissues. Journal of Biological Chemistry 226, 497-509.

Fring, C., Dunn, R., 1970. A colorimetric method for determination of total serum lipids based on the sulfophospho-vanillin reaction. American Journal of Clinical Pathology 53, 89-91.

Gutiérrez, M.L., Rodríguez, E.M., 2010. Effect of protein source on growth of early juvenile redclaw crayfish Cherax quadricarinatus (Decapoda, Parastacidae). Freshwater Crayfish Freshwater Crayfish 17, 23-29.

Hartley, B., 1996. An Atlas of British Diatoms. Biopress Limited, Bristol.

Hernández-Vergara, M., Rouse, D., Olivera-Novoa, M., Davis, D., 2003. Effects of dietary lipid level and source on growth and proximate composition of juvenile redclaw (Cherax quadricarinatus) reared under semi-intensive culture conditions. Aquaculture 223, 107-115.

Holl, C.M., Otoshi, C., Unabia, C.R., 2011. Nitrifying biofilms critical for water quality in intensive shrimp RAS. Global Aquaculture Advocate 14, 38-39.

Jones, C.M., 1997. The biology and aquaculture potential of the tropical freshwater crayfish, Cherax quadricarinatus. Information Series, vol. Q190028. Queensland Department of Primary Industries, Brisbane, Australia.

Jones, C.M., 1995. Production of juvenile redclaw crayfish Cherax quadricarinatus (von Martens) (Decapoda, Parastacidae) II. Juvenile nutrition and habitat. Aquaculture 138, 239-245.

Jones, P.L., Thanuthong, P.K., 2002. Preliminary study on the use of synthetic substrate for juvenile stage production of the yabby, Cherax destructor (Clark) (Decapoda: Parastacidae). Aquaculture Research 33, 811-818.

Krammer, K., Lange-Bertalot, H., 1986. Bacillariophyceae 1. Teil: Naviculaceae. In: Ettl, H., Gerloff, J., Heynig, H., Mollenhauer, D. (Eds.), Süsswasserflora von Mitteleuropa. Fischer, Jena.

Krammer, K., Lange-Bertalot, H., 2004. Bacillariophyceae 4. Teil: Achnanthaceae Kritische Ergänzungen zu Navicula (Lineolatae) und Gomphonema. In: Ettl, H., Gerloff, J., Heynig, H., Mollenhauer, D. (Eds.), Süsswasserflora von Mitteleuropa. Fischer, Jena.

Lee, J.J., Leedale, G., Bradbury, P.E., 2000. An Illustrated Guide to the Protozoa. Society of Protozoologists, Lawrence, K.S.

Lowry, O., Rosebrough, N., Farr, A., Randall, R., 1951. Protein measurements with the folin phenol reagent. Journal of Biological Chemistry 193, 265-275.

Loya-Javellana, G., Fielder, D.R., Thorne, M.J., 1994. Ontogeny of the foregut in the tropical freshwater crayfish, Cherax quadricarinatus (von Martens, 1968) (Parastacidae: Decapoda). Invertebrate Reproduction and Development 25, 49-58.
Marker, A.F.H., Nusch, A., Rai, H., Riemann, B., 1980. The measurements of photosynthetic pigments in freshwaters and standardization of methods: conclusions and recommendations. Archiv für Hydrobiologie-Beiheft Ergebnisse der Limnologie 14, 91-106.

Martínez-Fernández, E., Acosta-Salmón, H., Southgate, P.C., 2006. The nutritional value of seven species of tropical microalgae for black-lip pearl oyster (Pinctada margaritifera, L.) larvae. Aquaculture 257, 491-503.

Masser, M.P., Rouse, D.B., 1997. Australian Red Claw Crayfish. SRAC Publication, nº 244 USA.

Medley, P.B., Jones, C.M., Avault Jr., J.W., 1994. A global perspective of the culture of Australian redclaw crayfish, Cherax quadricarinatus: production, economics and marketing. World Aquaculture 25, 6-13.

Meyer-Reil, M., 1994. Microbial life in sedimentary biofilms - the challenge to microbial ecologists. (Rewiew). Marine Ecology Progress Series 112, 303-311.

Meyers, S.P., Latscha, T., 1997. Carotenoids. In: D'Abramo, L.R., Conklin, D.E., Akiyama, D.M. (Eds.), Crustacean Nutrition-Advances in World Aquaculture. The World Aquaculture Society, Baton Rouge, L.A., pp. 164-193.

Moss, K.R.K., Moss, S.M., 2004. Effects of artificial substrate and stocking density on the nursery production of pacific white shrimp Litopenaeus vannamei. Journal of the World Aquaculture Society 35, 537-542.

Pissetti, T.L., 2005. Efeito da densidade de estocagem e do substrato artificial no cultivo do camarão-rosa Farfantepenaeus paulensis (Pérez-Farfante, 1967) em cercados. Dissertação de Mestrado, Fundação Universidade Federal do Rio Grande, Rio Grande, Brazil, pp.57

Ramesh, M.R., Shankar, K.M., Mohan, C.V., Varghese, T.J., 1999. Comparison of three plant substrates for enhancing carp growth through bacterial biofilm. Aquacultural Engineering 19, 119-131.

Renaud, S., Thinh, L.V., Parry, D.L., 1999. The gross chemical composition and fatty acid composition of 18 species of tropical Australian microalgae for possible use in mariculture. Aquaculture 170, 147-159.

Schlechtriem, C., Ricci, M., Focken, U., Becker, K., 2004. Mass produced nematodes Panagrellus redivivus as live food for rearing carp larvae: preliminary results. Aquaculture Research 35, 547-551.

Sokal, R.R., Rohlf, F.J., 1995. Biometry: The Principles and Practice of Statistics in Biological Research, third ed. W.H. Freeman and Company, New York.

Stuart, J.A., Melony, J., Sellars, P., Crocos, J., Coman, G.J., 2006. Intensive production of juvenile tiger shrimp Penaeus monodon: an evaluation of stocking density and artificial substrates. Aquaculture 261, 890-896.

Tacon, A.G.J., 1999. Aquafeeds and the Oceanic Institute's AQUAFAN Program. Global Aquaculture Advocated 2, 14-16.

Thompson, F.L., Abreu, P.C., Cavalli, R., 1999. The use of microorganisms as food source for Penaeus paulensis larvae. Aquaculture 174, 139-153.

Thompson, F.L., Abreu, P.C., Wasielesky Jr., W., 2002. Importance of biofilm for water quality and nourishment in intensive shrimp culture. Aquaculture 203, 263-278.

Tidwell, J.H., Webster, C.D., Coyle, S.D., Daniels, W.H., D'Abramo, L.R., 1998. Fatty acid and amino acid composition of freshwater prawns, Macrobrachium rosenbergii (de Man), raised in fertilized ponds, unfertilized ponds, or fed prepared diets. Aquaculture Research 29, 37-45.

Van Handel, E., 1965. Estimation of glycogen in small amounts of tissue. Analytical Biochemistry $11,256-265$.

Verhoef, G.D., Jones, P.L., Austin, C.M., 1998. A comparison of natural and artificial diets for juveniles of the Australian freshwater crayfish Cherax destructor. Journal of the World Aquaculture Society 29, 243-248.

Verri, T., Mandal, A., Zilli, L., Bossa, D., Mandal, P., Ingrosso, L., Zonno, V., Vitella, S. Ahearn, G., Storelli, C., 2001. D-Glucose transport in decapod crustacean hepatopancreas. Comparative Biochemistry and Physiology 130A, 585-606.

Viau, V.E., Rodríguez, E.M., 2010. Substrate selection and effect of different substrates on survival and growth of juveniles of the freshwater crayfish Cherax quadricarinatus (von Martens 1868) (Decapoda, Paratacidae). Aquaculture International 18, 717-724.

Wasielesky Jr., W., Atwood, H., Atokes, A., Browdy, C.L., 2006. Effect of natural production in a zero exchange suspended microbial floc based super-intensive culture system for white shrimp Litopenaeus vannamei. Aquaculture 258, 396-403.

Whal, M., 1989. Marine epibiosis I. Fouling and antifouling: some basic aspects. Marine Ecology Progress Series 58, 175-189.

Zhang, B., Li, W.H., Huang, J.R., Wang, Y.J., Xu, R.L., 2010. Effects of artificial substrates on the growth, survival and spatial distribution of Litopenaeus vannamei in the intensive culture condition. Iranian Journal of Fisheries Sciences 9, 293-304.

Zhukova, N.V., Kharlamenko, V.I., 1999. Sources of essential fatty acids in the marine microbial loop. Aquatic Microbial Ecology 17, 153-157. 